\title{
THE REPRESENTATION OF WOMEN SCIENTIST IN AGORA
}

\author{
Mundi Rahayu
}

Email: mundi_rahayu@yahoo.com
Fakultas Humaniora dan Budaya Universitas Islam Negeri Maulana Malik Ibrahim Malang

Alamat Korepondensi: Jalan Gajayana 50 Malang 65144

\begin{abstract}
The research aims to explore the representation of woman scientist in film Agora. Agora is a film focusing on the life of a woman scientist and philosopher named Hypatia who lived in Alexandria at the end of $4^{\text {th }}$ A.D. The research uses semiotics that is applied to explore the signs and the meaning of the film. The signs are in the forms of visual and verbal signs, such as the image, dialogue, setting of place, plot, character, narration, etc. The result of the analysis shows that Hypatia is represented as a legend in astronomy and philosophy who dedicated all her life for science. Beside represented as a scientist, Hypatia is also an icon of sexual freedom though her choice for not getting married. She wants to make sure that she gets her liberty as any other man so that she is able to pursue the knowledge. Her reputation as a scientist, a rationalist, a skeptics bring her into her own symbolical power. Such symbolical power and unwillingness to subjugate to the dominant power leads her to her tragic end of her life. Hypatia is one of the first victims in the clash of science and the intolerance of religion. Though some historical inaccuracy, the films shows that the film maker confidently made a particular interpretation on the history. The social cultural setting of the story is on the rise of Christianity and the fall of Paganism in Alexandria at the end of 4 AD. This culminated in the destruction of the famous Library of Alexandria, where the largest part of the ancient Greek knowledge in mathematics, astronomy, philosophy and literature was preserved.
\end{abstract}

\section{Keywords}

Agora, Hypatia, Representation of Woman, Alexandria, Pagan

\section{Introduction}

Along history, woman has been represented in many ways in literary works and other cultural forms. Woman scientist is among the rare depiction of human history. Maybe it is because of the very few of woman scientist in the earth. It is always interesting then to discuss women representation in many field of study because of several reasons. The first, it is a challenging job to explore women representation because of strong hold stereotype of women. Second, women representation is always closely related to the intertwined relations between culture and power. So, exploring women's roles and position can lead to learn the roles and position of woman at a certain time and her contribution to the civilization because there is relationship between the women position and power. Second, by understanding woman's contribution people are able to improve the condition that is benefited for woman so that human's life is getting better and better. Third, by understanding woman's roles and contribution the knowledge resulted will be less biased.
This research focuses on the representation of woman in a film under the title Agora. This film is a historical drama film focused on the main female character, Hypatia of Alexandria, a scientist of 4 AD. The film is directed by Alejandro Amenábar and written by Amenábar and Mateo Gil. The main character, Hypatia, starred by Rachel Weisz, is a female mathematician, philosopher and astronomer in 4th century Roman Egypt who investigates the flaws of the geocentric Ptolemaic system and the heliocentric model that challenges it. The main character, an intellectual woman, lived in the situation of religious turmoil and social unrest. She struggles to save the knowledge of classical antiquity from destruction. The other characters Max Minghella co-stars as Davus, is Hypatia's slave, and Oscar Isaac as Hypatia's student Orestes, prefect of Alexandria are supporting characters in the film. 


\section{Conclusion}

The film Agora represents the woman legend of scientist, astronomer and philosopher, Hypatia of Alexandria. The social cultural setting of the story is on the rise of Christianity and the fall of Paganism in Alexandria at the end of $4 \mathrm{AD}$. This culminated in the destruction of the famous Library of Alexandria, where the largest part of the ancient Greek knowledge in mathematics, astronomy, philosophy and literature was preserved

The title Agora refers to the place where the pagan and the Christian meet at the beginning of their conflict, contested their different beliefs in such a way, that it triggered the next worse and sometimes bloody conflict. It is a starting point showing that the agora is not neutral, it is a place where the power of each group are contested. This place is overpowered by the dominant group.

Although Agora is an historical film, it is not only meant to look at the past, but also set to be the reflection of contemporary condition of religionbased violence, because of the similarity of the political situation of Alexandria and the contemporary world. As we can see in the film, Alexandria as a multi-religion community of diverse origin was in its dead end when Christianity was not only recognized as an official religion of the Empire, but as the only one accepted by the political power

The main character of the film, Hypatia, is represented as a philosopher, a scientist who dedicated all her life for science. She is depicted as beautiful, mature, talking intelligently and acting liberally as Hypathia, a pagan intellectual from a patrician family. Hypatia is busy thinking and discussing the problems of astronomy and mathematics that have been proposed by Ptolemy and Euclid.

Beside represented as a scientist, Hypatia is also an icon of sexual freedom though her choice for not getting married. She wants to make sure that she gets her liberty as any other man so that she is able to pursue her search of knowledge. Her reputation as a scientist, a rationalist, a skeptics bring her into her own symbolical power. Such symbolical power and unwillingness to subjugate to the dominant power leads her to her tragic end of her life. Hypatia is also one of the first victims in the clash of science and the intolerance of religion.

Watching the history of Hypatia in film Agora will lead the spectator to the conclusion that the film is not only a cinematic journey to the past, during the fall of Alexandria. The issue presented in this film is also contextual of the contemporary condition in which the importance of dialogue for safeguarding pluralism in contemporary politics.

The issue of this film, especially on the point of the cause of Hypatia's murder is very sensitive historical matter. Controversies among those agree and disagree on the cause of her murder did not stop the director of the film to make decision on a particular interpretation on the issue. As a work of art, film director and scenario writer has the right to make interpretation that they are able to be responsible for, though it brings controversies. The conflict between science and faith, between genders, and among religious groups are all still very contextual nowadays and it seems that the world has not changed a lot.

\section{REFERENCES}

Anderson, Sandra, et al. 2006. Dictionary of Media Studies. London: A\&C Black Publishers.

Artemi, Irene A. The Historical Inaccuracies of the Movie AGORA by Alejandro Amenabar http://www.johnsanidopoulos.com/2010/02/historical-inaccuracies-of-movie-agora.html

Barker, Chris. 2004. The Sage Dictionary of Cultural Studies. London: Sage

Barker, Chris.2004. Cultural Studies Theory and Practice, New Delhi: Sage.

Darrol M. Bryant. 1982. "Cinema, Religion, and Popular Culture," in Religion in Film, eds., John R. May and Michael Bird. Knoxville: University of Tennessee Press.

Eriyanto . 2001. Analisis Wacana: Pengantar Analisis Teks Media. LKiS. Yogyakarta.

Fairclough, Norman. 1989. Language and Power. UK: Longman Group UK Limited. 
Fiske, John. 2007. Cultural and Communication Studies, Sebuah Pengantar paling Komprehensif. Jogjakarta: Jalasutra.

French, Philip, Agora, The Observer, Sunday 25 April 2010 in http://www.guardian.co.uk/film/2010/apr/ 25/agora-review

Hall, Stuart. 1997. Representation Cultural Representations and Signifying Practice. USA: The Open University. Sage Publication. Ltd.

Margaret Miles. 1996. Seeing and Believing: Religion and Values in the Movies. Boston: Beacon Press.

Martin, Bronwen and Felizitas Ringham. 20002. Martin Dictionary of Semiotics. London: Cassell

Sanidopoulos, John. 2009. Agora: Film about Hypatia of Alexandria. Accessed in http://www.johnsanidopoulos.com/2009/05/agora-film-about-hypatia-of-alexandria.html 